ARTICLE

DOI: $10.1057 /$ s41599-017-0026-z

\title{
Regeneration, restoration and resurrection: scholastic inquiries into the nature of bodily growth and decay
}

\author{
Chris Gilleard ${ }^{1}$
}

\begin{abstract}
Beginning in the twelfth century, a renaissance in Western European learning took place as law, medicine, natural philosophy and theology began to emerge as academic disciplines. Functioning in the context of a Christian world view, concerns over the 'truth of human nature' and the status of the body led numerous scholastic writers to focus on matters of the body, its growth and decay, ageing and longevity, life and death. Such issues that had long preoccupied the world of antiquity were re-oriented by the juxtaposition of medicine, philosophy and theology in the schools of Bologna, Montpelier and Paris. Stimulated in part by theological questions concerning the state of the body at the time of creation, after the fall and its re-constitution at the resurrection, the introduction of newly translated works by Aristotle, Avicenna and Galen saw these concerns expand into systematic attempts to explain ageing, longevity and the preservation of health. Within this tradition, Arnold of Villanova's treatise on the radical moisture serves as an important illustration of these developments. While his writing was rooted in classical medicine and philosophy, less orthodox undercurrents can be detected seeking to preserve youth and extend life by alchemy and magic. Such treatises vied with the orthodoxies of Aristotle and Avicenna, while claiming the authority of the learned doctors themselves. This paper concludes by suggesting that both traditions-the orthodox and the heterodox-are evident to this day, even if couched in different terminologies.
\end{abstract}

\footnotetext{
${ }^{1}$ UCL, Division of Psychiatry, London, UK. Correspondence and requests for materials should be addressed to C.G. (email: C.Gilleard@ucl.ac.uk)
} 


\section{Introduction}

he mechanisms underlying human reproduction, growth and decay have been the subject of intellectual enquiry for as far back as recorded history goes. They posed particular challenges for early Christian thinkers as a result of doctrinal debates concerning the nature of bodily resurrection (Bynum, 1990, p 52). The material resurrection, restoration or 'regurgitation' of the body at the last judgement had become a crucial article of faith that was finally ratified at the Fourth Lateran Council, in 1215, making any alternative, more 'symbolic' forms of resurrection heretical propositions. This regulation in canon law added a new dimension to classical pre-Christian concerns with the nature of life and death and the processes of growth and decay, namely how might the body be understood as both mortal, in the sense of being born, growing and dying and yet becoming immortal, in the sense of being re-assembled and re-constituted as the previous, mortal body, living on ever after the day of judgement (Bynum, 1995; Reynolds, 1999). Developing a satisfactory understanding of these processes linked to a more general consideration of the problem of ageing and the possibilities for preventing or even reversing the ageing process well before its final resurrection.

These concerns emerged as particularly acute preoccupations among the thinking classes from the twelfth century onwards. Arguably this was the result of two changes in medieval culture. The first was the re-emergence of more 'spiritual' interpretations of the resurrection which questioned the materiality of the resurrection, rendering it disturbingly unclear to some in what state, and from what elements the body was expected to be reconstituted and how the scriptures represented that reconstitution and resurrection. At the same time, the rise of the medieval universities and the emergence of theology as an academic rather than a pastoral discipline created the conditions whereby a new generation of scholastic theologians were encouraged to turn their attention to such issues (Rosemann, 2010). While some chose to evade this problem, pursuing a purely theological approach, others turned to engaging more directly with natural philosophy and medicine, in what might be called the new materialism associated particularly with the newly introduced works of Aristotle (Bynum, 1990; Reynolds, 1999, p 69). The access to his works, translated into Latin from earlier Arabic translations made available a new materialistic framework by which the body could be understood as a corporeal entity 'embodying' the soul'.' Aristotle's natural philosophy, his writings on growth and decay, on the length and shortness of life, on youth, old age, and on life and death became the object of a number of scholastic commentaries from the middle of the thirteenth century (Dunne, 2003, p 324). But before exploring this scholastic tradition and its ideas of growth decay and regeneration, it is helpful to review briefly those of Aristotle's works that had entered Western scholarship during the eleventh and twelfth centuries, and their integration with the Hippocratic and Galenic traditions that permeated the medical school syllabus of late antiquity.

Aristotle on growth decay and the life cycle. The works of Aristotle provide the critical backdrop to much scholastic writing on growth and decay, the shortness and length of life. Most were first translated into Latin during the twelfth century 'renaissance' (Rosemann, 2010). These include his writings on generation and corruption ('De Generatione et Corruptione'), his treatise on the soul ('De Anima') and his short treatises on nature ('De Parva Naturalia'), particularly those concerning the length and shortness of life ('De Longitudine et Brevitatate Vitae'), and youth and old age, life and death ('De Juventate et Senectute, Vita et Morte'). ${ }^{2}$ The aim of this section is to provide a brief overview of these works as they entered the Western world as well as some of the commentaries that have since been made upon them.

In these writings, Aristotle sought to clarify what the distinction was between living and non-living matter, how living things possessed both form and substance and how living things arose, changed and eventually decayed and how they returned to an inorganic state. Critical to these processes were the intrinsic properties of living matter as 'nature' and the necessary interaction that takes place between living things and their environment, particularly through the ingestion of food or nutrients, but also from the air that was breathed, the climate in which life was nourished and the manner of living that the environment demanded. For Aristotle, the key to living matter in contrast to inorganic non-living matter was realised in and through the activity of the soul which conferred the form that life would take - that shaped its nature (King, 2001, p 22).

For Aristotle all living matter embodied a soul that determined life's nature. The soul, however embodied, existed in three distinct forms. At its most primitive it operated as a vegetative or nutrimental soul. This was common to all forms of life from plants to human beings. Next came the sentient soul that was common to all forms of animal life that could perceive and respond to its environment but which was not present in plants. Finally came the rational soul, that distinguished human from other forms of animal life because of its power of reason. The soul was responsible for the self-nutrition of living things-in the sense of their ingestion of nutriments, and the transformation of those nutriments into the growing organism and into the means of the organism's capacity for reproduction-in the sense of generating new living beings. While different forms of living matter exhibited different potentials for the overall level of complexity their ultimate form possessed, what was common to all forms of life was the capacity for self-nutrition, which in turn provided the necessary condition both for growth-and for decay.

His writings address a central concern that would play a critical role in later scholastic writing on life, death and resurrection. This was the process by which non-living matter is converted into living matter-digestion-so that it ceases at some point to be what it once was-food-and becomes at some other point part of the living thing that consumes it. This process presented three issues, first what can or cannot serve as food, secondly what happens to the food that turns it into the living body, and thirdly how the living body maintains its same form despite the addition of food and therefore the addition of external matter. In order to address what process underlies these three issues, Aristotle has to pin down what the nutritive soul is, or at least how it might best be understood. In a detailed examination of Aristotle's views on life and death, King has argued that life was seen by Aristotle as the necessary conjunction between body and soul. Without its embodiment, the nutritive soul per se was merely a principal or potential; its function could only be realised through and within the living body to which it gave its form as a thing of nature (King, 2001, p 43). In short life for Aristotle, life could only exist-could only come to be-through this interaction between matter, form as living matter's directing principle and the transformational powers of the vegetative soul.

Aristotle recognised that the creation of new life was only possible by the interaction of living creatures, whether via sexual or asexual reproduction and that the origin of the new life-the seed-was itself the product of nutrition. In other words that seeds or semen were products of growth and growth the product of nutrition. Plants left without soil and water and animals deprived of food and drink will not be able to reproduce; they will decay. Hence, both growth and generation (reproduction) depend upon nutrition. He argued that growth was not simply an increase in 
size or bulk: it involved the ingestion of external matter-food-into the substance of living matter, and its subsequent conversion into the living matter that incorporated it: thus, in one of his examples, the hay the horse eats at some point stops being hay and becomes horse. This process of assimilation is realised through the formative power of living matter; its capacity to direct the process of assimilation which is its capacity to grow while retaining its form (which the hay cannot) and the mechanism of 'concoction' that enabled this assimilation to take place.

The formative power Aristotle claims resides in the soul but can only be realised through the body. Hence there is a boundary or final form that exists and that is realised by the soul in the body-a natural limit to the body's growth which is determined by the soul, and which then determines the point at which 'wasting away can begin' (King, 2001, p 51). The assimilation of food into the body takes place through a process of 'concoction' that renders the materiality of food as potential body material (in effect digestion) and a second process that directs and incorporates that concocted, potential body material into the various parts of the growing body. These two processes of concoction and assimilation are thought to be regulated by the balance between what is taken in, how well it is 'concocted' and finally how completely it is 'assimilated'. The vegetative or nutrimental soul controls these processes so that the rate of growth, the eventual size at maturity and the rate of decay are all determined by its formative principle (King, 2001, p 58).

How then does Aristotle explain the cessation of growth and the onset of decay, if nutrition continues throughout life? To use King's terminology-'what is it about living things that is suited to perishing?' and what accounts for the differences in their rates of 'perishing' (King, 2001, p 59). To address this problem, Aristotle introduces the concept of innate or connate heat-the heat that the living body possesses from the moment of its gestation that enables it to 'concoct' food into potential body. In a sense this innate heat is the tool of the vegetative soul by which food is digested and transformed into potential body material. This innate heat, which is necessary to sustain life, is also critical in bringing about death since it can burn itself out, as it were, unless there is a matching process whereby the innate heat is preserved. That process is respiration - the cooling of the innate heat that preserves its vitality, and hence its capacity to enable food to be digested, transformed and directed toward growth and maintenance (King, 2001, p 106). Aristotle implies that 'life fails its possessors when the heat which is associated with it is not moderated by cooling for then...the heat is consumed by itself (Aristotle, 1957, 478b, p 10). Over time, he says, the lungs become dry and less efficient in functioning while the innate heat itself lessens as 'most of it has been breathed away' (Aristotle, 1957, $479 \mathrm{a}, \mathrm{p}$ 19). Old age (or withering) is consequently due to the failure of respiration to balance nutrition - specifically the inability of the organ 'to cause refrigeration' with the resultant burning out of the innate heat of the heart, itself grown weaker with the passage of time and the diminution of its 'power' when the body reaches 'its appointed end' (Aristotle, 1957, 479b, p 4).

While Aristotle recognises that life and death can be distinguished by the qualities of matter - their heat or cold, moisture or dryness - the factor that determines growth decay and death lies in the innate heat of the body, which serves as the mechanism for concocting food into assimilable matter. Innate heat, though centred in the heart, is spread throughout the body where it serves to both concoct and direct the concocted matter toward strengthening growing and maintaining the various organs flesh and bone that makes up the living being. As the body's form reaches maturity, the innate heat operates at its most efficient, and the organs are at their most powerful in keeping the balance between form and matter. With time, this balance begins to fail: the innate heat is no longer preserved and it is used up too quickly, drying out the organs which in turn become less adept at preserving their heat. Ageing ensues, and if it were to continue unaffected by external events, would lead to the gradual failure of regulation to maintain the innate heat, which slowly burns itself out. Thus death, natural death, brings old age to what Aristotle believed would be a painless end, in the absence of any violent disease, with the release of the soul occurring 'quite imperceptibly' (Aristotle, 1957, 479a, p 22).

Aristotle's scholastic commentators. Although Aristotle's writings provided a rich source of material for the theologians of the high Middle Ages, their commentaries have received rather 'scant attention' from contemporary scholars (Dunne, 2003, p 362). The assimilation and modification of Aristotle's works furnished much of what might be called 'the material base' for thirteenth and fourteenth century scholars, when they considered the problems of life and death, growth and decay, the resurrection and restoration of the body and the determinants of the length of life. Dunne, for example, identified numerous thirteenth century commentaries on Aristotle's works, addressing the topic of longevity and the determinants of the life span, including those of Albertus Magnus (Albert the Great), Peter of Ireland, Peter of Auvergne, and Thomas Aquinas. Set against these authors were others such as Peter Lombard who actively resisted Aristotle's natural philosophy and argued that food remained always external to the human body-and hence could never form what was called the truth of human nature-'veritas humanae naturae' (Reynolds, 1999, p 50). Such writers claimed that the truth of human nature would be resurrected as the body on the day of judgement, but with none of the extraneous elements that might have been introduced into the body during the person's mortal lifetime whether by nutrition or by other factors such as disease or disfigurement. They were, in a sense, a bridge between the old theology and the new materialism.

Peter Lombard (d. 1160) and the nature of the resurrected body. Peter Lombard's writings have been seen as constituting "the locus classicus" for twelfth century discussions on the resurrection of the body (Bynum, 1995, p 121). In the second and fourth volumes of his major work, known as 'Sententiae IV Libris Distinctae' (Four Books of Sentences) Lombard was especially concerned with the materiality of the resurrected body, which he sees as being put back together (re-assembled) element by element, while at the same time being in form, 'without corruption or burden or difficulty' (Bynum, 1995, p 124). In order to support this contention, Lombard had to consider the problem of nutrition and growth during the person's life. According to Bynum, Lombard saw the corporeality of the body at resurrection as sharing the essential materiality that the body had possessed in life-its shape, size, sex etc.-but none of its imperfections, including that of 'agedness'. Agedness and its opposite, immaturity, both reflected the imperfections of the flesh, much like deformities or bodily defects. The resurrected body would be perfect but particular to the individual him or her self-a perfect man or woman, a perfect slim or round person, etc.-but not an obese, ill or old person nor a baby. In this, Lombard represented the standard position of the church, and had no truck with either Plato or Aristotle who were taken to task because of their denial of the moment of creation (Rosemann, 2004, p 95). ${ }^{3}$

How did Peter Lombard make sense of the 'maturing' of the body-its reaching full size and its status at the point of resurrection? Since God had provided Adam and Eve with fruit and vegetables in the Garden of Eden, he had intended that they 
eat and drink, and that they be nourished. If that was true before the Fall, then these 'natural' processes must contribute to the perfecting of the body, and should also be present in the resurrected body. But if the body grows because of what we eat, Lombard worried, might we become not what we were but what we were not-food? The problem of the continuity of our corporeal identity (form) and the discontinuity of the materiality of our body led Lombard to re-frame growth as reflecting God's wondrous ways with each human being carrying within him or her self the 'truth of human nature' as it was passed down from Adam. In other words, rather than seek any materialist, physiological explanation he ended up with a materially inflected but essentially idealist position, albeit one drawing implicitly upon Aristotle's idea that all life contains, from its origins, its 'end', in the sense of a developmental endpoint or maturity. That was not, neither for Aristotle nor for the scholastics, old age. The so called 'truth of human nature' (veritas humanae naturae) though manifest in material form was constituted by idealised matter, and the body in its perfect form, was a body aged, more or less, 30 years (Bynum, 1995, p 126).

Lombard wrote that before the Fall, Adam and Eve had material bodies and were created as full adults with distinct sexual identities and with the intention that they reproduced and multiplied, though without lust or carnal pleasure (Lombard, 2008, p 86-87). Following the Fall, Lombard argued, original sin entered Adam and Eve's bodies not as something external but as part of the materiality of their bodies, leading them to become mortal beings subject to ageing, decay and death (Lombard, 2008, p 82-83). What they transmitted to successive generations was a material essence that remained untouched by food or the environment but which was corrupted by their original sin. The coming to be and the later decay and death of the body took place without affecting this essence, the truth of their human nature, but as the material consequence of the Fall. At the point of resurrection, he argues, the body will be reconstituted as an individual body, at the perfect age-'the measure of the age of the fullness of Christ' (Lombard, 2010, p 238). It will be reconstituted out of the matter of the body, not replaced piece by piece, or organ by organ, but re-fashioned out of the material that constituted the body in its intended not actual form (Lombard, 2010, p 240).

In short Peter Lombard's view of resurrection paid little attention to the new natural philosophy beyond the assumption that every body brought to life through human reproduction contained the essence of the first human beings that were fashioned and came to be fully formed at creation. Those bodies contained the potential to be immortal, but their material nature was corrupted by eating from the tree of knowledge. As a result their offspring-the whole of the human race-were condemned to be born in pain and to grow and decay as finite mortal beings. Even so, all human beings contained the potential to be resurrected as whole material beings, their state of 'corporeal perfection' being determined by the virtues with which they had lived as mortal beings. Although he does not say as much, the assumption seems to be that sinners would not be resurrected in anything like the same 'perfect' state as those without sin (Rosemann, 2004, p 183). On the other hand, for those whose sins were forgiven, the twelfth century theologians insisted that they should have faith that at the resurrection God 'the artificer' will cause: "fresh flowers from dryness and youth re-made from old age" (Peter the Venerable, 1954, p 267). ${ }^{4}$

Albertus Magnus and the material body. Despite the 'creationism' expressed by Peter Lombard and his apparent disdain for Greek philosophy, the ideas of materiality reflected in Aristotle's writings began permeating the centres of learning in France and Italy. This engagement contrasted markedly with the attitude of an earlier generation of theologians like Lombard, leading to more nuanced and arguably more sophisticated ideas concerning human nature, longevity and the processes of growth and decay. Bynum has argued that the unity that Aristotle perceived between the corporeality of the body and the embodied soul grew more salient in thinking about the resurrection during the 'high' middle ages when scholastics like Albert the Great (Albertus Magnus, d.1280) and Thomas Aquinas (d.1274) began to engage more fully with his writings. Their various commentaries, synopses and treatises turned from the principles and possibilities of reassemblage and regurgitation of the body toward the idea of a 'restoration of nature'. Resurrection was increasingly seen as the reflection, not of a spiritual or miraculous reconstruction, but as the fulfilment of intended nature: the unification of body and soul 'implicit in human ontology' (Bynum, 1995, p 246).

Cadden and Reynolds have both provided particularly detailed accounts of Albertus Magnus' writings on the subject of bodily growth and decay and it is from their accounts that I shall draw most upon (Cadden, 1971; Reynolds, 1999, p 215-312). Albert is one of the first great interpreters of Aristotle in the Latin West. Based in Paris, Albert exemplified the 'universal doctor', covering the principal scholastic disciplines of medicine, natural philosophy and theology (Cadden, 1980, p 321). Amongst his many works were commentaries on Peter the Lombard's Sententiae, Aristotle's De Generatione et Corruptione and De Anima and numerous treatises on topics from the resurrection, life and death, nutrition to man and the animals. What is particularly significant in Albert's writings, for present purposes at least, is his integration into these discussions of the concept of moisture-the humidities-in the active process of growth and decay. In his commentary and elaboration of Aristotle's De Generatione et Corruptione, he claims that growth is achieved through two operations, one through the action of a radical moisture which informs growth and a second through the action of a nutrimental moisture which materialises growth. Left unchecked, the innate heat of the body would use up the body's substance, were it not replenished by these moistures (humidities). While the original moisture that is present from conception determines the form that the body becomes (the truth of human nature), the nutrimental moisture is derived from external sources-food and drink-and adds or helps assimilate the nutriment into the body, causing it both to grow and once grown, to maintain its form. It is from the ingestion of food and the creation of the nutrimental moisture that the beginnings of decay set in, for it is but an imperfect substitute for the radical or original moisture (Cadden, 1971, p 81).

While Aristotle had emphasised the role of the innate heat (and its preservation through the cooling influence of respiration) Albert introduced a second quality or process determining growth and decay, based upon the moistures (the humidities). This concept (though linked to the two sets of opposing qualities of hot and cold, moist and dry that have their roots in preSocratic Greek philosophy) is not present in Aristotle and comes in fact from Avicenna's Canon of Medicine. Drawing upon humoral theory, in the Canon, Avicenna develops the idea that bodies are formed grow and decay through the functions of the primary and secondary humours (Avicenna, A Treatise on the Canon of Medicine, [trans. Gruner O C 1930] Book I, Fen 1, Thesis III, S. p 57-59). Another point raised in Albert's commentaries concerns growth and the restoration of parts. This is a digression from Aristotle's own writings, but one which has an obvious bearing upon the potential or lack of potential for bodily re-growth. Albert notes that in some living creatures, especially in simpler forms of life like plants and some 'primitive' 
animals, the destruction of part of their body is capable of being restored through self-nutrition. Leaves cut off re-grow: even among some animals, if a part of their body or a limb is cut off, a replacement limb or body part can re-grow. In most animals however, while the loss of flesh or bone, hair or nails is readily replaced, loss of specific organs like the hand or the lips, the fingers or the arm cannot. His explanation for this differential 'restorability' lies in the spatial distribution of the formative principle within the body. The more complex the living creature, the less centralised is this 'formative' principle, being instead distributed within the various organs. While those parts of the body that are undifferentiated like hair or flesh can and do grow back, those that are differentiated like the hand or the lungs once lost or destroyed cannot be replaced (Cadden, 1971, p 119).

For Albert, then, there are three principles at work in growth and decay. First, there is the formative principle that is distributed somewhat differently in living creatures according to the complexity of their overall form. In complex animals, this formative principle is not centralised but resides within the various organs of the body. The second principle is the active role of the body in directing nutriment to its parts. This is spread equally throughout the body, although its most powerful action derives from the innate heat within the heart. Finally, there is the process whereby nutriment is transformed from an external substance into potential and then actual bodily substance, through the process of concoction into a generic nutrimental moisture which serves as an imperfect substitute or support for the primary innate moisture that triggers growth from the moment of conception, the radical moisture. It is the continuous presence of the radical moisture throughout the body that effectively directs the process of nutrimental assimilation (Cadden, 1971, p 135).

This latter principle comes as an addition to Aristotle's model, and as already noted, most probably derives from Avicenna or commentaries upon Avicenna. Albert draws upon the same metaphor of the lamp that Avicenna employed in the Canon (Reynolds, 1999, p 275). He argues that there are as it were two forms of humidity or moistures in the lamp, one in the well and the other soaked up within the wick. As the flame consumes the moisture in the wick, it is replaced by the moisture in the well but this latter moisture is less oily and more watery. Consequently the flame is less effectively supported as the moisture from the well gradually dilutes and replaces the original moisture of the wick (Reynolds, op. cit., p 275). The more complex the living creature, the more reliant each organ or part of its body is to the support from the original, radical moisture and the less easily can the nutrimental moisture substitute for it. Hence simple regeneration of the body of complex highly differentiated living creatures is impossible because they are more entirely reliant upon the radical moisture inherent in their members and organs to effect their growth. Losing their members means losing the radical moisture within them and no central nutrimental moisture can be drawn up to regenerate those lost parts (Reynolds, 1999, p 279). In effect, it is the finite nature of both the radical moisture and the innate heat that determine first the cessation of growth and secondly the decay of that which has reached its 'natural' limits of growth. Thus for Albert there exists a determinant of longevity, and that resides in the balance between the innate heat and the innate moisture, While nutriment can support the innate moisture, it is an imperfect substitute lacking both the former's formative power and its efficient power to sustain the innate heat, leading to both the cooling and the drying of the body - that is, its ageing and subsequent decay (Cadden, 1971, p 140-142).

In his De Resurrectione, Albert addresses the relationship between the resurrected body and the nutriment it had assimilated during the course of its mortal life (Reynolds, 1999, p 281-310). Returning to the question of the truth of human nature that was discussed by Peter Lombard, Albert argued that the resurrected body (a) would return united with its soul and in its corporeal form (b) which would consist of the most dignified/ noble elements of the body in life and (c) with that precise 'quantity' of the body required by the substantial form of the individual human being (Reynolds, 1999, p 307-308). This formulation leads Albert to define the different degrees of corporeal dignity/nobility assigned to the body. He distinguishes not only between the 'radical' or 'seminal' moisture and the 'acquired' or nutrimental moisture, but also between two types of seminal moisture and three types of nutrimental moisture (Reynolds, 1999, p 301). The first distinction is between the seminal moisture that is embodied by semen and the moisture that derives from the womb that is necessary for the embryo to develop 'in utero'. Both are part of the truth of human nature and both will be reconstituted during the resurrection. Of the three types of nutrimental moisture, he distinguishes between that which contributes to the growth of the body, that which contributes to the maintenance of the body and that which is added unnecessarily, a superfluous moisture. The implication-which he does not make clear-is that while both types of seminal moisture will be present in the resurrected body, as will that nutrimental moisture which enabled the form of the body to grow to its inherent size and shape (its natural form), those nutrimental moistures that played no part in realising the body's natural form or that contributed to the 'deforming/ decaying' of the body will not. In that sense neither ageing disease nor the superfluous moisture that contributes to decay form any part of the truth of the body so none will be present in the body at the resurrection. This of course corresponds with the widespread view of the church that the resurrected body will have the perfect age embodied by Christ at his death, namely 'thirty-two years and three months' (Lombard, 2010, p 239).

Albert merged the concept of the body's natural/innate heat (coming from Aristotle) with the concept of its seminal moisture (coming from Avicenna) to establish a model of the life cycle and its stages of growth maturity and decay based upon the 'balance' between these two. The lamp metaphor, elaborated in Avicenna's Canon, and derived from Galen, provided Albert with the analogy that illustrated this process and that indicated the mechanism of ageing and decay, namely the loss of radical moisture and the burning out of the innate heat. His writings furnished a template for further developments in thinking about growth, maturity, decline and death during the fourteenth century. Such 'biological' theorising would become less concerned with the specifics of the resurrected body, and focus much more upon issues to do with the determination of longevity and the 'naturalness' or otherwise of ageing as experienced at that time. This in turn would be incorporated into the various regimens of health and 'ageing well' that would come to dominate writing on ageing in the renaissance (Gilleard, 2013).

Various explanations have been put forward to account for this shift in emphasis, including developments in medical, philosophical and theological learning, the turn within theology toward issues of heaven, hell and purgatory rather than the last day of judgement, the shift in focus in the doctrinal dispute within theology and the encouragement afforded by systems of medical patronage for learned doctors to demonstrate their value as learned doctors and devisors of regimes of health for the bodies of the secular and sacred elites of Europe (Bynum, 1990, p 53; Fitzpatrick, 2013; Le Goff, 1984; Paravicini-Bagliani, 2000, p 193). As Arnold of Villanova said of Pope Boniface VIII, even he had become more concerned with maintaining his health and prolonging his life than with the health of souls (ParaviciniBagliani, 2000, p 227) 
Arnold of Villanova's treatise on radical moisture. The work of Arnold of Villanova represents a further development in the evolution of ideas about ageing and longevity in the pre-modern period. Unlike Albertus, Arnold (d. 1311) trained as a doctor and later served as the private physician to popes, princes and other potentates Gerwing, 2011, p 119. Like Albertus his writings covered all three disciplines of medicine philosophy and theology but it was his theological writing on the imminent arrival of the Anti-Christ that landed him in trouble with the Church authorities. Imprisoned for heresy for his writings on the Anti-Christ, he was freed by the next Pope. He continued to carry this reputation for heresy-and for more dubious practices of magic and necromancy-long after his death (Giralt, 2013). According to Ziegler, Arnold epitomised the 'theologising physician' (Ziegler, 1995, p 255) with links to both medicine and theology who 'perceive[d] his art as a quasi-religious system' and 'extended his professional preoccupation with purging the body of its malignant humours to the mystical body of the Church which he diagnosed as diseased' (Ziegler, 1995, p 303).

His treatise on the radical moisture ("Tractatus De Humido Radicali"), written while he was based at the University of Montpelier, some time between 1295 and 1300, was neither a medical nor a theological tract but intended as a contribution to natural philosophy. Still, it can be seen as following within, and indeed helping maintain a tradition that derives from the earlier theological concern with the 'veritas humanae naturae' as outlined in the writings of Peter the Lombard (Crisciani and Ferrari, 2010, p 346; Reynolds, 2001, p 44). The treatise provides a critical exploration of the concept of the 'humidum radicale' (radical moisture) and its role in both growth, ageing and the determination of the length of life, set against alternative but unnamed philosophers and thinkers whose views he condemns and often ridicules (Crisciani, 2005). Arnold considered his treatise as a work of philosophy, designed to clarify the nature of the radical moisture, the possibilities for and limits to its restoration through nutrition-though he ended it with due recognition of God's role in determining all things (Arnold of Villanova, 2010, p 318). ${ }^{5}$ The rhetorical aim he gave for writing the treatise was to create a more definitive understanding of this crucial element of life, while shooting down the various, erroneous views of other 'plebeian and ignorant philosophers' lacking even the common knowledge of farmers and peasants (Arnold of Villanova, 2010, p 285).

The treatise is organised into two main sections, the first addressing what the radical moisture is and what it is not (namely not semen) and the second considering the arguments for and against the possible restoration ['restaurantione'] of the radical moisture, reaching the conclusion that while restoration is possible, such restoration has its limits beyond which it cannot go; these limits being equivalent to the limits of longevity (Arnold of Villanova, 2010, p 313). Arnold argues that in creating new life, semen/sperm enters into shaping the new body not as material semen but as the formative principle shaping the new body. It is distributed equally throughout the growing embryo, just as seeds create new plants but in doing so, become part of the plant rather than remaining as seed. In short the radical moisture may derive from the sperm, but in forming the new body and in conferring living heat throughout its whole form, the radical moisture spreads throughout the radical members not in the material form of sperm but as the vehicle that animates [brings innate heat to] the members. In doing so, it necessarily combines with flowing or nutrimental moisture, derived originally from the menstrual blood then from the mother's milk, and after weaning from food. Thus the radical moisture provides both the source of fuel for the innate heat and the stimulus for growth to realise the intended form of the body. However, from shortly after conception, the radical moisture is co-mingled with nutrimental moisture, in order to provide the material basis for further growth. Thus, despite its radical nature, this formative radical moisture acquires a capacity to be 'corrupted' because (a) it needs to co-opt nutriment to enable growth and (b) if it alone were able to sustain not just generation but growth and maturation, then there would be no reason for any living matter to perish or decay. The radical or 'root' moisture is deemed incorruptible since it contains the formative principle that creates the 'radical members' (i.e., the basic structures of the body); the body grows and decays because its growth involves an inter-mixing of the radical moisture with the nutrimental moisture, like the adulteration of wine with water.

In the second volume, Arnold goes on to consider how nutriment contributes to and mixes with the radical moisture to sustain growth; how its co-mixture places limits on growth; and how the continuing co-mixture of the two moistures eventually leads to a maintenance failure, whereby the parts of the body lose the power to generate heat because of the continuing 'adulteration' of the radical moisture, which brings about the drying out of the body - that is its ageing or decaying, leading inexorably to the extinction of bodily heat and death. After explaining that the regeneration of body parts is rendered impossible because each part of the body once formed only contains the means to nourish itself, and not a generic set of replicating instructions that existed prior to the formation of parts, Arnold then explains how growth comes to an end as the body parts gradually dry out, harden and become less capable of further extension (Arnold of Villanova, 2010, p 309). He adds that as the moisture supplying the body parts becomes less like the radical moisture so it becomes less able to contribute to their growth. The embryo grows most quickly in the womb, when it is nourished by the menstrual blood which is closest to the radical moisture that generated it in the first place. It continues to grow but not quite so rapidly, after birth when it is nourished by its mother's milk. Finally as it relies more upon external nutriments, growth slows down even further until eventually no further growth of the body parts is possible. Arnold acknowledges that animals - including human beings - can still continue to grow in size, however, from eating more food, but that what then constitutes the increase in size is increases in fleshiness or fatness, neither of which are the radical members of the body but which are in their constitution more like the digested food itself (Arnold of Villanova, 2010, p 309).

Thus the radical moisture which initiates or lies at the root of the gestation and development of the embryo is seen to sustain growth by enabling the nutrimental moisture to serve that function. To begin with, the nutrimental moisture is more akin to the radical moisture since it derives from the menstrual blood. As that is replaced by nutriment obtained by food, it loses its power to maintain the innate heat of the living body while the radical members lose their moisture and become less extendable. This balance between the corruption of the radical moisture by the nutrimental moisture and the consequent drying out of the radical members and the accompanying loss of their innate heat leads to first the cessation of growth, then the decay and drying of the radical parts of the body culminating in death. In short "the cause of natural death is the corruption of life-giving heat, caused by the corruption [dissimilarity] of the nourishing power" (Arnold of Villanova, 2010, p 314).

If however the process of natural death is a complex function of the ratio of life giving heat to the capability of the moisture to restore and inform it sufficiently for life, Arnold considers whether it might be possible for men to determine that ratio and in effect maintain the necessary balance indefinitely-to make life immortal. While he recognises that doctors can interfere with the body through the prescription of various regimens that may serve to preserve the innate heat or maintain the innate moisture, since 
no-one other than God can calculate the precise ratio of heat and moisture needed throughout each part of the human being, altering the natural course of life determined for each individual life is in practice impossible. Consequently, he says, the best a doctor can do is removing all impediments that prevent the 'natural' lifespan being realised and when doctors speak of delaying death or old age, or of prolonging life and youthfulness, it needs to be understood that what they really mean is guarding against all forms of accidental death (Arnold of Villanova, 2010, $\mathrm{p}$ 318). With the wish that God grants us a full 'natural life' and the hope that his treatise might fall into the hands of at least one intelligent man, he concludes.

It is perhaps no coincidence that one of Villanova's medical colleagues at Montpelier, Bernard di Gordan, was responsible for including in his treatise on 'ageing' and 'marasmus' (wasting away) a recipe or elixir to render the one who took it 'insenescible' (Demaitre, 1992, p 283). Villanova himself had written various prescriptive regimens to promote health and even prepared a treatise advocating vegetarianism as particularly suiting the frail (Bazell 1995, p 232). He also had a treatise on prolonging life and preserving youth attributed to him, although it is generally considered the work of some other unknown late medieval writer (Crisciani, 2005; Giralt, 2013). As Luke Demaitre points out, the conflict between interpreting nutrition as the source of life (e.g., through the consumption of a healthy diet) and as the cause of the ending of life (through the corruption induced by the impurities of nutrimental moisture) was played out in the promotion of dietary regimens which has continued to the present day (Demaitre, 1992). Although the theological concerns over the state of the body at the resurrection faded away, the problem of the 'truth of human nature' would continue to exercise thinking minds. Possibilities for deferring or delaying ageing remain, clinging perhaps to the idea that ageing is indeed in some way 'unnatural' and not part of 'the truth of human nature. ${ }^{6}$

\section{Conclusions}

To determine the 'truth of human nature', medieval scholars began by wrestling with the issue through theology and the interpretation of scripture. As theological interest shifted away from the 'true' nature of the body and its material status at the resurrection and as Aristotle's natural philosophy gained an increasing foothold in the universities, medieval writing incorporated more materially invested explications. This turn to Aristotle and Avicenna reframed the question toward philosophical issues of growth and decay, ageing and mortality, with the idea that ageing might be better managed in this world even as it would be finally excluded from the next. Arnold of Villanova's treatise on the radical moisture exemplifies this transformation from the purely theological speculations on the 'veritas humanae naturae' exemplified in Peter Lombard's Sentences, to the integration of ideas from the new universities' other disciplines of medicine and philosophy.

Where once the theological problem of the resurrection acted as a stimulus for such leading figures as Albertus Magnus to seek the integration of Christian belief with Aristotelian materialism, the increasingly worldly concerns of princes popes and patrons gradually nudged these discussions toward a desire for a longer life and the potential for a restoration of the aged or decaying body in this life-a criticism that was levelled against Pope Boniface VIII by Arnold of Villanova (Manselli, 1951, p 18; Paravicini-Bagliani, 2000, p 227). The desirable state of the body remained in Christian teaching, the form that it was intended to be, before the Fall, and exemplified in the body of Jesus at the crucifixion, namely that of a thirty year old healthy human being. Aristotle's writings provided a theoretical model for re-interpreting this truth of human nature integrating the phenomena of nutrition, growth and the role of the innate heat in causing both the coming to be and the corruption of living matter. Drawing upon this, Albert the Great added ideas derived from a second model, drawing upon the medical writings of Galen and especially, of Avicenna. Within this latter tradition, it was moisture and not just heat that serves as a determinant of growth and decay and that determines the length of life, through the consumption or rather the corruption of the 'innate' 'seminal' or 'radical moisture'.

Arnold of Villanova's treatise on the radical moisture has been used as an illustration and exemplar of this way of thinking about age and the length of life. Arguably Bacon's treatise, De Retardatione Accidentium Senectutis could have been used instead. However, this work is less unequivocally attributed to Bacon than the Tractatus is to Arnold and is widely recognised as being a much weaker analysis and description of growth, ageing and decay (Ferrari, 2005, p 281; Getz, 1997, p 347; Giralt, 2013). At the same time, within the De Retardatione, there was evident a third alternative narrative that existed somewhat outside established medicine, philosophy and theology, in the less scholarly traditions of alchemy and magic. In contrast to the measured ideas of the scholastics concerning the underlying mechanisms of longevity, the naturalness or otherwise of old age, and the fundamental impossibility of ever truly grasping the nature of divine purpose, an alternative literature proposed magical short cuts to ever longer lives, and to bodily restoration. These writings were often attributed to the likes of learned doctors such as Albert the Great, Roger Bacon and Arnold of Villanova and relied upon realising rejuvenation and 'insenescibilitas' through the consumption of 'youth inducing' qualities derived on magical principles from seemingly 'ageless' rare or esoteric material such as the bone of the stag's heart, coral and powdered gold (Ferrari, 2005, p 291). ${ }^{7}$

By the time of the scientific revolution of the seventeenth century, many of these preoccupations were beginning to fade away. Regimes for promoting health and living well in old age continued, but the preoccupations both with the truth of human nature and with bodily restoration/rejuvenation had long since faded. Despite Francis Bacon's desire to make the determination of the length of life the central concern of the new science, the problem of ageing, longevity and death would not emerge as an active scientific concern for at least a couple of centuries. Then, as new powers in nature began to be explored at the turn of the twentieth century, a new imaginary of rejuvenation emerged, mediated by discoveries concerning internal secretions (hormones), the new applications of medical electricity, the discovery and the use of radio-activity. Possessing seemingly magical properties, these newly discovered 'forces' were realised by clinical scientists whose work would lead to the development of such modern medical specialties as endocrinology, experimental neurology and nuclear medicine. But as with the scholastics, their work would be re-fashioned. Brown-Séquard, the founder of endocrinology and one of, if not the founder of experimental neurology, for example, would provide the source for innumerable 'rejuvenating' elixirs produced in the wake of his clinical experiments (Borell, 1976). Such discoveries opened up new opportunities for charlatans and scammers as well as for the subsequent development of anti-ageing/regenerative medicine, even as they seemed to close down a universal faith in corporeal resurrection in the world to come. The new faith in scientific medicine has continued to mix hopes and hypotheses, medicine and magic as much as did its pre-modern precursors.

Received: 8 May 2017 Accepted: 17 October 2017

Published online: 14 November 2017 


\section{Notes}

1 Although Aristotle's treatment of the soul was 'materialistic' it was quite capable of being re-interpreted in a more spiritual way as already evidenced in the Islamic philosophy of Avicenna and Averroes (Duart, 2000).

2 All references are either to The Basic Works of Aristotle [ed. R McKeon], New York, 2001-De Generatione and De Anima-or to Hett's translation of the De Longitudine and De Juventate from Parva Naturalia, Loeb, Harvard, 1957.

3 In De Generatione, Aristotle considered both celestial and 'sub-lunar' material as eternal and cyclical, with the distinction being that sub-lunar material, living matter particularly, was generated, decayed and was recreated in a cyclical manner, whose species identity remained unchanging, despite the constant change of the individual identities embodying that species identity (see for example Averroes' commentary on De Generatione, Averroes, 1958, 338b, p 11-19).

4 Peter the Venerable, d. 1156.

5 The pagination used to reference this work is that supplied in the edited Latin edition re-produced under the auspices of the University of Barcelona's collection of de Villanova's complete medical writings.

6 We might see today's parallel as the argument that ageing or senescence is not built in our genes even if it is a by-product of their actions (cf. Kirkwood, 2001, p 26).

7 Examples rendered/translated into English from the Latin include pseudo-Bacon's “ $D e$ Retardatione Accidentium Senectutis" and pseudo-Arnold of Villanova's "De Conservanda Juventute et Retardanda Senectute" - see Giralt (2013).

\section{References}

Albertus Magnus (1958) De sacramentis: De incarnatione: De resurrectione. Alberti Magni. Opera Omnia, Tomus XXVI, Münster, Verlag Aschendorff

Aristotle (1957) On length and shortness of life, and On youth and old age, life and death. In: Hett WS (ed) Parva Naturalia. Harvard University Press, Cambridge, MA, p 388-411, trans. p 412-429

Aristotle (2001) De Generatione et corruptione, De Anima, and De Generatione animalium. The Basic Works of Aristotle. The Modern Library, New York, NY, p 470-531, p 535-604, p 665-680

Averroes (1958) On Aristotle's De Generatione et Corruptione: Middle commentary and epitome (trans: Kurland S). The Mediaeval Academy of America, Cambridge, Mass

Bazell DM (1995) “De Esu Carnium”: Arnold of Villanova's defence of Carthusian abstinence. Arxiu de Textos Catalans Antics 14:227-248

Borell M (1976) Brown-Séquard's organotherapy and its appearance in America at the end of the nineteenth century. Bull Hist Med 50(3):309-31

Bynum CW (1990) Material continuity, personal survival and the resurrection of the body: A scholastic discussion in its medieval and modern contexts. Hist Relig 30(1):51-85

Bynum CW (1995) The Resurrection of the Body in Western Christianity. Columbia University Press, New York, NY

Cadden J (1971) The medieval philosophy and biology of growth: Albertus Magnus, Thomas Aquinas, Albert of Saxony and Masilius of Inghen on Book I, Chapter V of Aristotle's 'De Generatione et Corruptione,' with translated texts of Albertus Magnus and Thomas Aquinas. Unpublished Ph.D. thesis, Indiana University. (ProQuest Dissertations Publishing, 1971, no.7212948)

Cadden J (1980) Albertus Magnus' universal physiology: the example of nutrition In: Weisheipl JA (ed) Albertus Magnus and the Sciences: Commemorative Essays 1980. Pontifical Institute of Mediaeval Studies, Toronto, p 321-339

Crisciani C (2005) Aspetti del dibattito sull'humido radicale nella cultura del tardo medioevo (Secolo XIII - XV). Arxiu de Textos Catalans Antics 23/ 24:332-384

Crisciani C, Ferrari G (2010) Introduzione: le conoscenze e l'uso dei teologi. In: McVaugh MR (ed) Arnaldi de Villanova Opera Medica Omnia, v.2, Tractatus de Humido Radicali. Publicacions de la Universitat de Barcelona, Barcelona, p 345-366

Demaitre L (1992) The medical notion of 'withering 'from Galen to the fourteenth century: the treatise on marasmus by Bernard of Gordon. Traditio 47:259-307

Duart T-A (2000) The human soul's individuation and its survival after the body's death: Avicenna on the causal relation between body and soul. Arabic Sci Phil 10:259-273

Dunne M (2003) Thirteenth and fourteenth-century commentaries on the De Longitudine et Brevitate Vitae. Early Sci Med 8(4):320-335

Ferrari G (2005) Il trattato de humido radicali di Arnoldo da Villanova. Arxiu De Textos Catalans Antics 23/24:281-331

Fitzpatrick A (2013) Bodily Identity in Scholastic Theology. UCL, London, http:// discovery.ucl.ac.uk/1411124/1/FITZPATRICK 730544\%20PhD\%20Thesis. pdf. Unpublished Ph.D. Thesis, UCL. Accessed 3 Nov 2017

Gerwing, M. 2011. Arnoldus de Villanova, In: Lagerlund H (ed) Encyclopaedia of Medieval Philosophy, Philosophy between 500 and 1500. Springer Science and Business Media, Dordrecht, Netherlands, pp 119-121
Getz F (1997) Roger Bacon and medicine: The paradox of the forbidden fruit and the secrets of long life, In: Hackett J (ed) Roger Bacon and the Sciences: Commemorative Essays. Brill, Leiden, p 337-364

Gilleard C (2013) Renaissance treatises on 'successful ageing'. Ageing Soc 33 (2):189-215

Giralt S (2013) The legend of Arnau de Vilanova, from the Middle Ages to the Early Modern Times. Micrologus. Nat Sci Mediev Soc 21:411-444

Gruner O C (1930) A Treatise on the Canon of Medicine of Avicenna. London, Luzac \& Co

King RAH (2001) Aristotle on Life and Death. Duckworth, London

Kirkwood T (2001) The end of age: why everything about ageing is changing. Profile Books, London

Le Goff J (1984) The Birth of Purgatory. Scolar Press, London

Lombard P (2008) The Sentences: Book 2: On Creation (Mediaeval Sources in Translation 43: trans: G. Silano). Pontifical Institute of Mediaeval Studies, Toronto

Lombard P (2010) The Sentences: Book 4: On the Doctrine of Signs (Mediaeval Sources of Translation trans: Silano G). vol 48. Pontifical Institute of Mediaeval Studies, Toronto

Manselli R (1951) La Religiosità d'Arnaldo da Villanova. Bulletino dell'Istituto Storico Italiano per il Medio Evo e Archivio Muratoriano, vol 63. Rome

McVaugh M (1974) The 'humidum radicale' in thirteenth century medicine. Traditio 30(3):259-283

Paravicini-Bagliani A (2000) The Pope's Body. University of Chicago Press, Chicago

Peter the Venerable (1954) Sermo in honore sancti illius cuius reliquiae sunt in presenti, In: Constable G (ed) Petri Venerabilis Sermones Tres: Revue Benedictine, vol 64. p 224-272

Reynold PL (1999) Food and the body: Some peculiar questions in high medieval theology. Brill, Leiden

Reynolds PL (2001) Growth, digestion, decay and resurrection. Hist Today 51 (6): $42-47$

Rosemann P (2004) Peter Lombard. Oxford University Press, Oxford

Rosemann P (2010) Philosophy and theology in the universities. In: Lansing C, English ED (eds) Companion to the Medieval World. Wiley-Blackwell, Oxford, UK, p 544-560

van't Land K (2014) Long life, natural death: The learned ideal of dying in late medieval commentaries on Avicenna's Canon. Early Sci Med 19(4):558-583

Villanova, Arnold of (2010) Tractatus de Humido Radicali. In: McVaugh MR (ed) Opera Medica Omnia. Publicacions de la Universitat de Barcelona, Barcelona p 283-318. v.2

Ziegler J (1995) Arnau de Vilanova: A case study of a theologizing physician. Arxiu De Textos Catalans Antics 14:249-303

Ziegler J (1999) 'Ut dicunt medici': Medical knowledge and theological debates in the second half of the thirteenth century. Bull Hist Med 73 (2):208-237

\section{Data availability}

Data sharing is not applicable to this paper as no datasets were analysed or generated.

\section{Additional information}

Competing interests: The author declares no competing financial interests.

Reprints and permission information is available online at http://www.nature.com/ reprints

Publisher's note: Springer Nature remains neutral with regard to jurisdictional claims in published maps and institutional affiliations.

Open Access This article is licensed under a Creative Common Attribution 4.0 International License, which permits use, sharing, adaptation, distribution and reproduction in any medium or format, as long as you give appropriate credit to the original author(s) and the source, provide a link to the Creative Commons license, and indicate if changes were made. The images or other third party material in this article are included in the article's Creative Commons license, unles indicated otherwise in a credit line to the material. If material is not included in the article's Creative Commons license and your intended use is not permitted by statutory regulation or exceeds the permitted use, you will need to obtain permission directly from the copyright holder. To view a copy of this license, visit http://creativecommons.org/ licenses/by/4.0/.

(C) The Author(s) 2017 